\title{
Pengaruh Tepung Kedelai Kaya Isoflavon terhadap Testosteron Serum, Jumlah Sel Leydig dan Jumlah Sel Spermatogenik pada Tubuli Seminiferi Testis Tikus (Rattus norvegicus)
}

\author{
The Effects of Isoflavone-riched Soybean Flour on Testosterone Serum, Total Leydig Cells \\ and Total Spermatogenic Cells in the Seminiferous Tubules of Male Rats Testes \\ Sussi Astuti ${ }^{1 *}$ dan Sutyarso ${ }^{2}$ \\ ${ }^{1}$ Jurusan Teknologi Hasil Pertanian, Fakultas Pertanian, Universitas Lampung \\ Jl. Prof Sumantri Brojonegoro No. 1 Bandar Lampung 35144 \\ ${ }^{2}$ Jurusan Biologi, FMIPA, Universitas Lampung \\ Jl. Prof Sumantri Brojonegoro No. 1 Bandar Lampung 35144 \\ E-mail: astuti_thp@unila.ac.id *Penulis untuk korespondensi
}

\begin{abstract}
The objective of this experiment was to evaluate the effects of isoflavone-riched soybean flour with different levels of isoflavone on testosterone level, total Leydig cells, and total spermatogenic cells in the seminiferous tubules of male rats. Diet was given as isonitrogen and isocaloric with $10 \%$ of dietary protein from casein. Twenty five male of Sprague Dawley weaning rats (21 days old) were divided into five groups and treated with isoflavone-riched soybean flour by oral administration with different levels (dosages). The treatment was conducted for 2 months. The treatment of isoflavone-riched soybean flour with higher dosage of isoflavone increased the testosterone levels in the serum and the total Leydig cells in the seminiferous tubules of male rats. The optimum dosage of isoflavone was $1.5 \mathrm{mg} /$ day resulted in the highest total spermatogenic cells of rat testes. The treatment isoflavone-riched soybean flour with $1.5 \mathrm{mg}$ isoflavone/day on male rats resulted in the testosteron level of $2.96 \pm 0.45 \mathrm{ng} / \mathrm{ml}$, total Leydig cells 70.22 \pm 9.34 ; while the number of spermatogonia, spermatocytes, early spermatids, late spermatids, and total spermatogenic cells were $48.44 \pm 4.82,60.00 \pm 3.43,221.56 \pm 16.12$, $164.33 \pm 17.94$, and $494.33 \pm 32.94$, respectively.
\end{abstract}

Key words: Isoflavone-riched soybean flour, testosterone, Leydig cells, spermatogenic cells

\begin{abstract}
Abstrak
Tujuan penelitian ini adalah untuk mengevaluasi pengaruh tepung kedelai kaya isoflavon pada berbagai tingkatan dosis isoflavon terhadap kadar hormon testosteron serum, jumlah sel Leydig dan jumlah sel spermatogenik pada tubuli seminiferi testis tikus jantan. Ransum basal kasein disusun secara isonitrogen dan isokalori dengan kadar protein ransum sebesar 10\%. Dua puluh lima ekor tikus jantan strain Sprague Dawley umur sapih (21 hari) dibagi dalam lima kelompok dan mendapat perlakuan tepung kedelai kaya isoflavon secara oral dengan berbagai tingkatan dosis isoflavon. Perlakuan diberikan selama dua bulan. Hasil penelitian menunjukkan bahwa pemberian tepung kedelai kaya isoflavon dengan dosis isoflavon yang semakin tinggi secara signifikan menyebabkan peningkatan kadar hormon testosteron serum dan peningkatan jumlah sel Leydig. Dosis isoflavon 1,5 mg/ekor/hari merupakan dosis optimum yang menghasilkan total sel spermatogenik tertinggi. Pemberian tepung kedelai kaya isoflavon dengan dosis isoflavon 1,5 mg/ekor/hari menghasilkan : kadar hormon testosteron serum 2,96 $0.45 \mathrm{ng} / \mathrm{ml}$; jumlah sel Leydig 70,22 $\pm 9,34$; jumlah sel spermatogonia, spermatosit, spermatid awal, spermatid akhir dan total sel spermatogenik masing-masing sebesar 48,44 $\pm 4,82$; $60,00 \pm 3,43 ; 221,56 \pm 16,12 ; 164,33 \pm 17,94 ;$ dan $494,33 \pm 32,94$.
\end{abstract}

Kata kunci: Tepung kedelai kaya isoflavon, testosteron, sel Leydig, sel spermatogenik 


\section{Pendahuluan}

Produksi spermatozoa serta sintesis dan sekresi testosteron berlangsung di dalam testis. Spermatogenesis merupakan suatu proses pembentukan spermatozoa yang terjadi secara berurutan, teratur, dan terus menerus. Proses spermatogenesis tergantung pada kerja hormon. Testosteron yang disintesis dalam jaringan interstisial oleh sel Leydig merupakan faktor endokrin penting dalam gametogenesis mamalia jantan. Menurut Tendean (2005), spermatogenesis dibedakan atas spermatogenesis yang normal secara kualitatif yaitu lengkapnya tipe sel germinal dan spermatogenesis yang normal secara kuantitatif yaitu lengkapnya jumlah sel germinal.

Testis sebagai tempat berlangsungnya spermatogenesis bersifat sangat rentan terhadap proses oksidasi oleh radikal bebas. Terdapatnya radikal bebas pada testis dapat mengubah kestabilan dan fungsi membran, akibat terjadinya proses peroksidasi lipid. Peroksidasi lipid dilaporkan Sanocka dan Kurpisz (2004) mengakibatkan gangguan spermatogenesis. Menurut Sikka (2004), terdapatnya radical scavenger akan membersihkan radikal bebas pada jaringan-jaringan yang memproduksi spermatozoa. Sistem pertahanan tubuh yang dapat digunakan untuk melawan radikal bebas dipengaruhi oleh tersedianya zat-zat gizi yang berasal dari bahan pangan yang memiliki potensi sebagai antioksidan.

Sebagai salah satu golongan flavonoid, komponen bioaktif isoflavon yang terkandung dalam kedelai dilaporkan mempunyai kemampuan sebagai antioksidan, dengan bertindak sebagai scavenger radikal bebas (Nijveldt et al., 2001). Dietary antioksidan sebagai scavenger radikal bebas akan membersihkan radikal bebas pada jaringanjaringan yang memproduksi spermatozoa, menekan proses oksidasi, peroksidasi lipid dan kerusakan sel spermatozoa, serta mencegah kondisi stres oksidatif sehingga diduga dapat mengurangi kasus infertilitas (Sikka, 2004).

Hasil penelitian yang telah dilakukan menunjukkan adanya kontroversi akibat pemberian kedelai, produk-produk olahan kedelai, dan produk turunan kedelai terhadap kesuburan jantan. Mitchell et al., (2001) menyatakan bahwa pada pria umur 18-46 th, konsumsi isoflavon yang terkandung dalam produk-produk olahan kedelai dengan dosis 40-70 mg/hari tidak memengaruhi kualitas spermatozoa dan hormon steroid. Atanassova et al., (2000) melaporkan perubahan berat testis, berkurangnya volume lumen pada tubuli seminiferi dan terganggunya spermatogenesis setelah tikus diberi genistein (salah satu bentuk isolat isoflavon murni) melalui injeksi pada dosis $4 \mathrm{mg} / \mathrm{kg}$ berat/hari. Sedangkan Fritz et al., (2003) melaporkan penurunan aktivitas aromatase testis tikus akibat pemberian genistein melalui jalur diet konsumsi secara normal pada dosis $250 \mathrm{mg} / \mathrm{kg}$ diet $( \pm 5 \mathrm{mg}$ /ekor/hari).

Struktur molekul isoflavon kedelai mirip dengan struktur molekul estrogen, sehingga dikenal sebagai fitoestrogen. Hal ini menyebabkan isoflavon kedelai dapat berikatan dengan reseptor estrogen (RE), tetapi afinitas RE ligan tersebut lebih rendah dibanding estrogen endogen (Miksicek, 1994). Sel epitel dari jaringan reproduksi seperti kelenjar susu, ovari dan testis merupakan subjek dari aksi isoflavon (Anderson dan Garner, 2000). Mekanisme aksi biologis estrogen adalah kemampuannya untuk bertindak sebagai estrogen agonis yang dapat berikatan dengan RE dan menstimulasi respons estrogen, atau bertindak sebagai estrogen antagonis yang dapat berikatan dengan RE tetapi menghambat respons estrogen (Helferich et al., 2001). Aksi spesifik fitoestrogen dengan keberadaan estrogen endogen tergantung pada konsentrasinya, yaitu aksi agonis terlihat ketika estrogen terdapat pada konsentrasi rendah, sedangkan aksi antagonis terlihat pada estrogen konsentrasi tinggi (Brzozowski et al., 1997; Wang dan Kurzer 1998 diacu dalam Robertson et al., 2002).

Untuk lebih mencerminkan apa yang sesungguhnya terjadi akibat konsumsi pangan alami sumber isoflavon terhadap kadar hormon testosteron, jumlah sel Leydig dan jumlah sel spermatogenik pada tubuli seminiferi testis, dalam penelitian ini digunakan tepung kedelai kaya isoflavon. Tepung kedelai kaya isoflavon mengandung kadar isoflavon 3\%, dihasilkan dari biji kedelai tanpa proses kimia atau penambahan bahan tambahan pangan, serta 
mempunyai rasa dan aroma yang disukai (Anonim, 1998).

Tujuan penelitian ini adalah untuk mengkaji asupan antioksidan alami (isoflavon) yang terkandung dalam tepung kedelai kaya isoflavon pada berbagai tingkatan dosis terhadap kadar hormon testosteron, jumlah sel Leydig dan jumlah sel spermatogenik pada tubuli seminiferi testis dengan menggunakan tikus jantan sebagai model.

\section{Metode Penelitian}

Bahan utama yang digunakan dalam penelitian adalah tepung kedelai kaya isoflavon (TKI) dari perusahaan SoyLife Extra ORFFA BELGIUM NV, Ambachtsstraat 6-B-1840 LONDERZEEL. n-heksana digunakan untuk mengurangi lemak pada TKI sehingga diperoleh TKI rendah lemak (TKI-RL) (Astuti et al., 2008).

Untuk studi in vivo, digunakan tikus strain Sprague Dawley (SD) jantan umur 21 hari dari PT Indoanilab Bogor. Bahan penyusun ransum adalah kasein, mineral mix, vitamin mix, minyak jagung, selulosa, air dan pati jagung/maizena. Pengukuran kadar hormon testosteron serum menggunakan KIT Testosteron. Bahan kimia untuk pembuatan preparat jaringan testis dan proses pewarnaan Hematoksilin Eosin (HE) antara lain $\mathrm{NaCl}$, larutan fiksatif bouin, alkohol, xylol, parafin, hematoxylin, eosin, dan entellan.

\section{Perlakuan Hewan Percobaan (in vivo) dan Sampling}

Sebanyak 25 ekor tikus jantan SD umur sapih (21 hari) terlebih dahulu diadaptasikan di lingkungan laboratorium tempat percobaan selama 1 minggu. Ransum basal kasein disusun secara isonitrogen dan isokalori dengan kadar protein 10\%, modifikasi Anonim (1990) diberikan secara ad libitum. Bahan penyusun ransum tikus jantan adalah kasein, mineral mix, vitamin mix, minyak jagung, selulosa, air dan pati jagung/ maizena. Setelah masa adaptasi, tikus dibagi 5 kelompok: (1) Kontrol, cekok aquades; (2) cekok TKI-RL dosis isoflavon (IF) $1,5 \mathrm{mg} / \mathrm{ekor} / \mathrm{hari}$; (3) cekok TKI-RL dosis IF $3 \mathrm{mg} / \mathrm{ekor} / \mathrm{hari}$; (4) cekok TKI-RL dosis IF 4,5 mg/ekor/hari; dan (5) cekok TKI-RL dosis IF $6 \mathrm{mg} / \mathrm{ekor} / \mathrm{hari}$, sehingga terdapat 5 ulangan pada tiap-tiap kelompok.

TKI-RL diberikan pada tikus jantan dengan cara dicekok menggunakan sonde lambung, dengan melarutkan TKI-RL dalam $1 \mathrm{ml}$ aquades. Perlakuan diberikan selama 2 bulan. Pemberian TKI-RL pada tikus jantan secara in vivo dilakukan berdasarkan pengukuran kandungan total senyawa isoflavon. Hasil analisis dengan HPLC terhadap TKI-RL menunjukkan adanya tiga komponen senyawa isoflavon yaitu daidzein, genistein, dan glisitein dengan kandungan total senyawa isoflavon sebesar 2.22 $\mathrm{g} / 100 \mathrm{~g}$ bb (Astuti et al., 2008). Pada Tabel 1 disajikan formulasi ransum tikus jantan per $100 \mathrm{~g}$ ransum berdasarkan modifikasi Anonim (1990).

Pada akhir perlakuan, tikus jantan dikorbankan dengan dipatahkan tulang leher (dislocasio cervicalis). Kadar hormon testosteron serum diamati dari darah yang diambil pada bagian jantung. Bagian testis dikoleksi dan dilakukan pengamatan terhadap morfologi testis.

Tabel 1. Formulasi ransum tikus jantan per $100 \mathrm{~g}$ ransum.

\begin{tabular}{lrrrrr}
\hline \multicolumn{1}{c}{ Komposisi Bahan } & \multicolumn{3}{c}{ Perlakuan Isoflavon (mg/ekor/hari) } & \multicolumn{1}{c}{} \\
& $\mathbf{0}$ (Kontrol) & $\mathbf{1 , 5}$ & $\mathbf{3}$ & $\mathbf{4 , 5}$ & $\mathbf{6}$ \\
\hline Kasein (g) & 11,09 & 11,09 & 11,09 & 11,09 & 11,09 \\
Minyak jagung (g) & 7,92 & 7,92 & 7,92 & 7,92 & 7,92 \\
Mineral mix (g) & & & & & \\
$\quad$ ZnSO4.7H2O (mg) & 4,43 & 4,43 & 4,43 & 4,43 & 4,43 \\
Vitamin mix Fitkom (g) & 1 & 1 & 1 & 1 & 1 \\
$\quad$ Asam folat (mg) & 30 & 30 & 30 & 30 & 30 \\
$\quad$ Vitamin K (mg) & 5 & 5 & 5 & 5 & 5 \\
$\quad$ Vitamin E (mg) & 15,7 & 15,7 & 15,7 & 15,7 & 15,7 \\
Selulosa & 0,99 & 0,99 & 0,99 & 0,99 & 0,99 \\
Air & 4,38 & 4,38 & 4,38 & 4,38 & 4,38 \\
Pati & 70,19 & 70,19 & 70,19 & 70,19 & 70,19 \\
\hline \hline \multicolumn{1}{c}{ Jumlah } & $\mathbf{1 0 0 , 0 0}$ & $\mathbf{1 0 0 , 0 0}$ & $\mathbf{1 0 0 , 0 0}$ & $\mathbf{1 0 0 , 0 0}$ & $\mathbf{1 0 0 , 0 0}$ \\
\hline \hline
\end{tabular}




\section{Analisis Kadar Hormon Testosteron Serum (Anonim, 2003)}

Pengukuran konsentrasi hormon testosteron serum dilakukan dengan metode ${ }^{125} \mathrm{I}$ Radioimmunoassay (RIA) teknik fase padat menggunakan kit Coat A-Count ${ }^{\circledR}$ Total Testosterone. Prinsip kerja berdasarkan kompetisi antara testosteron serum dan testosteron berlabel ${ }^{125} \mathrm{I}$ untuk terikat pada antibodi yang spesifik terhadap hormon testosteron.

Untuk pengamatan terhadap kadar testosteron serum tikus jantan, darah diambil dari jantung pada pagi hari dengan menggunakan syringe steril sekali pakai, disimpan pada $5^{\circ} \mathrm{C}$ selama 2 jam, kemudian dilakukan pemisahan serum dengan menggunakan sentrifuge pada $5.000 \mathrm{rpm}$ selama 15 menit. Serum dimasukkan tabung eppendorf dan disimpan $-20^{\circ} \mathrm{C}$ sampai siap dianalisis.

\section{Pengamatan Sel Leydig dan Sel Spermatogenik (Kiernan, 1990)}

Organ testis dicuci dengan $\mathrm{NaCl}$ fisiologis $0,9 \%$, difiksasi dalam larutan Bouin selama 24 jam. Jaringan testis kemudian diproses dengan metode standar menggunakan parafin. Blok jaringan yang didapat dipotong $\pm 4 \mu \mathrm{m}$ dan dilekatkan pada obyek glass, sehingga diperoleh potongan jaringan (sediaan). Selanjutnya, dilakukan proses pewarnaan Hematoksilin Eosin/HE menggunakan metode Kiernan (1990). Proses pewarnaan diawali dengan proses pelarutan parafin menggunakan xylol (deparafinasi). Selanjutnya, dilakukan pengembalian kandungan air ke dalam jaringan (rehidrasi) menggunakan alkohol dengan konsentrasi yang menurun, dimulai dari alkohol $100 \%$ sampai dengan alkohol $70 \%$. Kemudian preparat diletakkan pada air mengalir, dicuci dengan aquadest dan diwarnai dengan larutan Hematoksilin. Preparat kembali diletakkan dalam air mengalir dengan tujuan agar warna Hematoksilin lebih kuat dan dicuci kembali dengan aquadest sebelum diwarnai dengan Eosin. Setelah diwarnai, kandungan air dalam jaringan ditarik kembali (dehidrasi) dengan alkohol dengan konsentrasi meningkat, mulai alkohol $70 \%$ sampai alkohol $100 \%$, kemudian dijernihkan (clearing) dengan xylol. Langkah terakhir adalah perekatan dengan entellan dan ditutup dengan kaca penutup (mounting). Setelah dilakukan pemotretan dengan mikrofoto, jumlah sel Leydig pada jaringan interstitial dan jumlah sel-sel spermatogenik pada tiap tahap perkembangan spermatogenesis dihitung pada sembilan tubuli seminiferi untuk tiga ulangan pada tiap kelompok perlakuan.

\section{Analisis Data}

Data diolah dengan uji sidik ragam menggunakan Rancangan Acak Lengkap (RAL) untuk mengetahui pengaruh perlakuan terhadap parameter yang diuji. Untuk mengetahui perbedaan antarperlakuan, data yang menunjukkan pengaruh nyata selanjutnya diuji dengan Duncan Multiple Range Test (DMRT).

\section{Hasil dan Pembahasan}

\section{Hormon Testosteron Serum dan Jumlah Sel Leydig}

Kelompok yang mendapat cekok TKIRL dengan empat tingkatan dosis isoflavon menghasilkan kadar hormon testosteron dan jumlah sel Leydig lebih tinggi dibanding kelompok kontrol. Hasil pengukuran terhadap kadar hormon testosteron (Gambar 1) sejalan dengan hasil perhitungan jumlah sel Leydig (Gambar 2) pada tubuli seminiferi testis tikus. Kelompok yang dicekok TKI-RL dengan dosis isoflavon (IF) 4,5 $\mathrm{mg} / \mathrm{ekor} / \mathrm{hari}$ dan 6 mg/ekor/hari menghasilkan kadar hormon testosteron dan jumlah sel Leydig yang paling tinggi secara nyata $(\mathrm{p}<0,05)$ bila dibanding kelompok lainnya. Tidak terlihat adanya perbedaan kadar hormon testosteron dan jumlah sel Leydig pada kelompok yang dicekok TKI-RL dengan dosis IF 1,5 dan 3 $\mathrm{mg} / \mathrm{ekor} /$ hari. Fotomikrograf sel Leydig pada testis tikus perlakuan disajikan pada Gambar 3. 


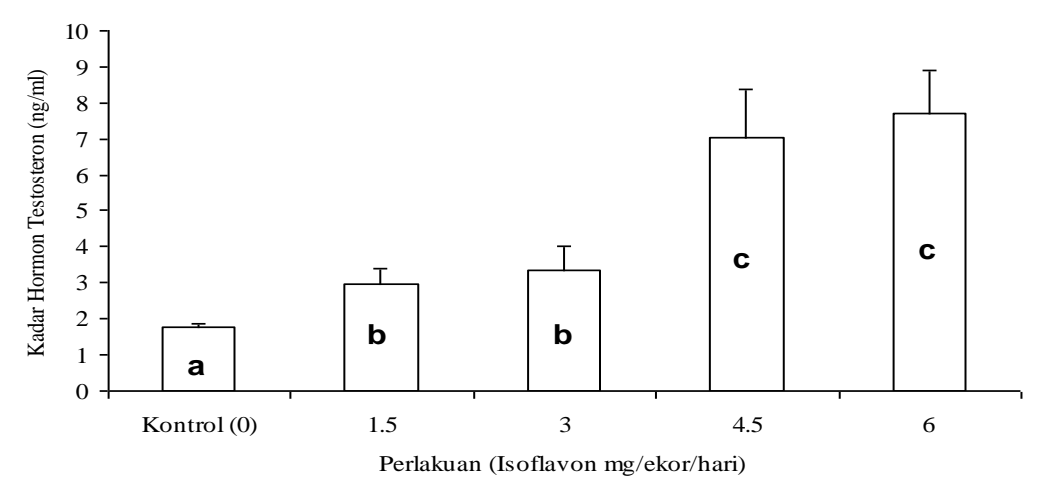

Gambar 1. Kadar hormon testosteron tikus pada berbagai variasi dosis isoflavon.

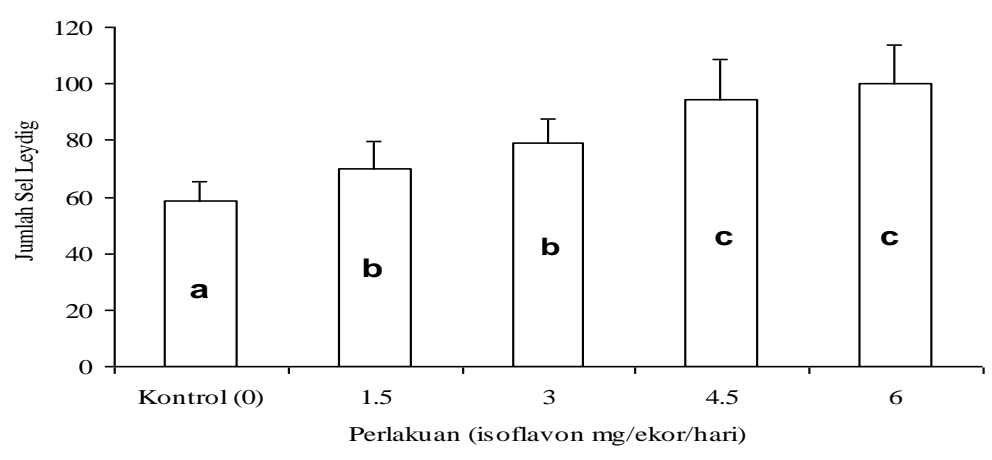

Gambar 2. Jumlah sel Leydig tikus pada berbagai variasi dosis isoflavon.

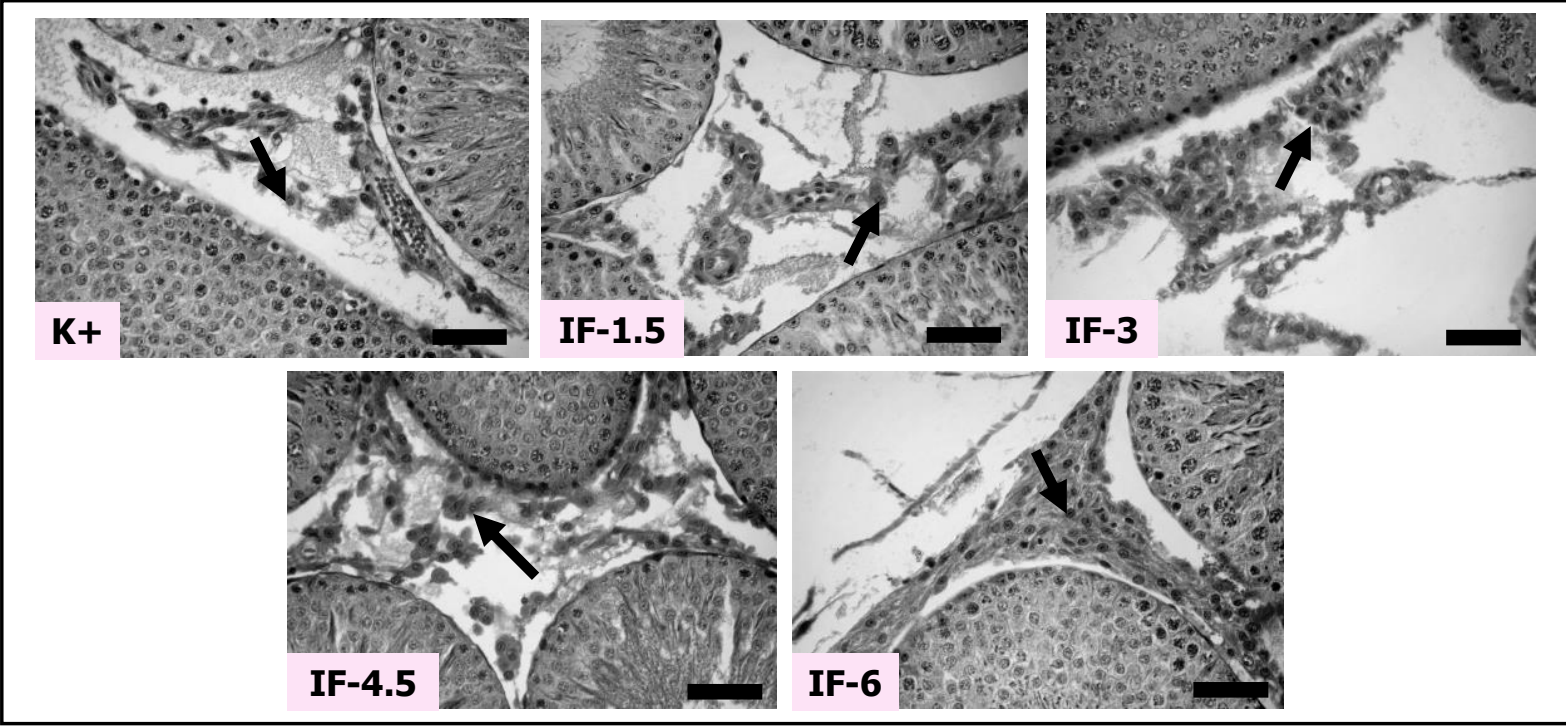

Gambar 3. Fotomikrograf sel Leydig pada testis tikus perlakuan. Jumlah sel Leydig tertinggi secara nyata terlihat pada kelompok tikus yang mendapat isoflavon dengan dosis 4,5 dan $6 \mathrm{mg} / \mathrm{ekor} / \mathrm{hari}$, dibandingkan kelompok tikus yang mendapat isoflavon dengan dosis 1,5 dan $3 \mathrm{mg} /$ ekor/hari. Jumlah sel Leydig terendah secara nyata terlihat pada kelompok kontrol. (Pewarnaan HE, skala $=20 \mu \mathrm{m}$ ) $\longrightarrow=$ sel Leydig.

$\mathrm{K}=$ Kontrol, cekok aquades $\quad \mathrm{I}-1,5=$ Isoflavon $1,5 \mathrm{mg} / \mathrm{ekor} / \mathrm{hari}$ I-3 = Isoflavon $3 \mathrm{mg} /$ ekor/hari $\quad \mathrm{I}-4,5=$ Isoflavon $4,5 \mathrm{mg} / \mathrm{ekor} / \mathrm{hari}$ $\mathrm{I}-6=$ Isoflavon $6 \mathrm{mg} / \mathrm{ekor} / \mathrm{hari}$ 
Peningkatan kadar hormon testosteron akibat pemberian TKI-RL sejalan dengan temuan Fritz et al., (2003), bahwa pemberian genistein (salah satu komponen senyawa isoflavon dalam bentuk isolat isoflavon murni) dalam diet tikus melalui jalur konsumsi secara normal (oral) pada kadar yang lebih tinggi akan meningkatkan kadar hormon testosteron. Fritz et al., (2003) melaporkan bahwa pada konsentrasi yang semakin tinggi, pemberian genistein secara signifikan menurunkan aktivitas aromatase testis. Lebih lanjut dinyatakan bahwa aktivitas aromatase testis kelompok kontrol (tanpa pemberian genistein) sebesar $100 \%$, kelompok yang diberi genistein $250 \mathrm{mg}$ genistein $/ \mathrm{kg}$ diet $( \pm 5 \mathrm{mg}$ genistein/ekor/hari) sebesar $81,6 \%$, sedangkan kelompok yang diberi genistein $1000 \mathrm{mg}$ genistein $/ \mathrm{kg}$ diet $( \pm 20 \mathrm{mg}$ genistein/ekor/hari) sebesar 74,8\%.

Pengukuran aktivitas aromatase testis untuk mengetahui kemampuan testis dalam mengonversi androgen menjadi estrogen (Hess, 2003). Pada mencit dewasa, aromatase ditemukan dalam sel Leydig dan sel germinal, yaitu daerah badan Golgi pada spermatid awal dan pada flagella spermatid akhir (Nitta et al., 1993), spermatosit pachytene dan spermatozoa dari epididimis (Janulis et al., 1998). Beberapa peneliti juga melaporkan keberadaan aromatase pada sel Sertoli tikus (Carreau et al., 1999). Pada manusia, defisiensi aromatase dilaporkan menyebabkan mutasi genetik yang berhubungan dengan problem infertilitas. Beberapa kasus memperlihatkan adanya penurunan konsentrasi spermatozoa akibat defisiensi aromatase pada manusia (Carreau et al., 2003). Defisiensi aromatase pada pasien oligospermia dilaporkan menyebabkan penurunan berat testis dan problem infertilitas (Carani et al., 1997 diacu dalam Luconi, 2002).

Konsentrasi genistein yang tinggi dalam diet tikus akan menghambat konversi testosteron ke estrogen, sehingga pengaruh tersebut berkontribusi menurunkan konsentrasi estrogen dan mengakibatkan peningkatan kadar hormon testosteron. Peningkatan testosteron setelah pemberian genistein merupakan akibat langsung dari penghambatan aktivitas aromatase, atau kemungkinan penghambatan aromatase oleh genistein terjadi sebagai respons meningkatnya konsentrasi testosteron (Fritz et al., 2003). Peningkatan konsentrasi testosteron dilaporkan Hess (2003) terjadi akibat gangguan pengaturan umpan balik pada hipotalamus, sedangkan Hafez dan Hafez (2000) menyatakan tingginya konsentrasi testosteron dalam darah menyebabkan mekanisme umpan balik negatif (negative feedback mechanism) terhadap hipofisis sehingga produksi LH dan FSH menurun. Penurunan kadar LH dan FSH akan menyebabkan hambatan proses spermatogenesis.

Kelompok yang dicekok TKI-RL dengan dosis IF 1,5 mg/ekor/hari dan $3 \mathrm{mg} /$ ekor/hari mengalami peningkatan kadar hormon testosteron yang lebih tinggi dibanding kontrol. Hal ini memberikan pengaruh yang lebih baik terhadap proses spermatogenesis mengingat kelompok yang dicekok TKI-RL dengan dosis IF $1,5 \mathrm{mg} /$ ekor/hari menghasilkan jumlah sel spermatogenik tertinggi (Gambar 4). Tingginya jumlah sel spermatogenik menunjukkan bahwa dosis IF $1,5 \mathrm{mg} / \mathrm{ekor} / \mathrm{hari}$ merupakan dosis optimum isoflavon yang terbaik.

Tingginya kadar hormon testosteron pada kelompok yang dicekok TKI-RL dengan dosis IF 4,5 mg/ekor/hari dan $6 \mathrm{mg} / \mathrm{ekor} /$ hari sejalan dengan peningkatan jumlah sel Leydig pada kedua kelompok tersebut. Sel Leydig merupakan tempat utama berlangsungnya sintesis hormon testosteron. Mengacu pada penelitian Fritz et al., (2003), diduga pemberian TKI-RL dengan dosis isoflavon yang semakin tinggi mengakibatkan rendahnya kadar estrogen akibat terhambatnya aktivitas aromatase. Dalam hal ini, peran isoflavon sebagai estrogen agonis pada dosis tinggi akan menstimulasi respon estrogen sehingga berpotensi menimbulkan gangguan. Aktivitas aromatase yang terhambat diduga menurunkan konsentrasi estrogen dan mengakibatkan kadar hormon testosteron meningkat. Akibatnya, setelah kedua kelompok tikus tersebut terekspos senyawa isoflavon pada dosis tinggi, testis tikus berpotensi mengalami perubahan dalam perkembangan, morfologi maupun proses spermatogenesis. Hal ini mengindikasikan bahwa telah terjadi perubahan steroidogenesis pada testis kedua kelompok tersebut. 


\section{Jumlah Sel Spermatogenik}

Kelompok yang dicekok TKI-RL dengan dosis IF 4,5 dan $6 \mathrm{mg} /$ ekor/hari menghasilkan total sel spermatogenik paling rendah secara nyata $(\mathrm{p}<0,05)$ dibanding kelompok lain, sedangkan total sel spermatogenik tertinggi dihasilkan kelompok yang dicekok TKI-RL dengan dosis IF $1,5 \mathrm{mg} / \mathrm{ekor} / \mathrm{hari}$. Tidak terlihat adanya perbedaan total sel spermatogenik pada kelompok kontrol dan kelompok yang dicekok TKI-RL dengan dosis IF $3 \mathrm{mg} / \mathrm{ekor} / \mathrm{hari}$ (Gambar 4). Rataan jumlah sel-sel spermatogenik tubuli seminiferi pada tiap tahapan spermatogenesis testis tikus perlakuan dengan berbagai variasi dosis isoflavon tersaji pada Tabel 2, sedangkan total sel spermatogenik setiap perlakuan disajikan pada Gambar 4. Gambaran histologis sel spermatogonia, spermatosit, spermatid awal dan spermatid akhir pada tubuli seminiferi setiap perlakuan disajikan pada Gambar 5.

Kelompok yang dicekok TKI-RL dengan dosis IF paling rendah $(1,5 \mathrm{mg} / \mathrm{ekor} / \mathrm{hari})$ menghasilkan total sel spermatogenik tertinggi dibanding kelompok yang dicekok TKI-RL dengan dosis IF yang lebih tinggi. Diduga, dosis $1,5 \mathrm{mg} / \mathrm{ekor} / \mathrm{hari}$ merupakan dosis isoflavon yang optimal dan efektif, di mana isoflavon berperan sebagai estrogen antagonis dengan bertindak sebagai antioksidan dan menghambat respon estrogen. Akibatnya, sel testis yang terlindung oleh antioksidan isoflavon mampu mempertahankan diri dari serangan oksidatif senyawa radikal bebas, akumulasi radikal bebas pada jaringan-jaringan yang memproduksi spermatozoa dapat dicegah, dan mampu melindungi fungsi spermatozoa. Dengan terlindungnya sel testis dari proses oksidasi, diduga proses spermatogenesis menjadi tidak terhambat atau terganggu.

Total sel spermatogenik kelompok yang dicekok TKI-RL dengan dosis IF $3 \mathrm{mg} / \mathrm{ekor} / \mathrm{hari}$ tidak berbeda dengan kelompok kontrol. Hasil ini memperlihatkan bahwa pemberian TKI-RL pada dosis IF $3 \mathrm{mg} /$ ekor/hari tidak memberikan pengaruh yang berarti terhadap total sel spermatogenik, baik pengaruhnya terhadap peningkatan maupun penurunan total sel spermatogenik.
Total sel spermatogenik terendah terlihat pada kelompok yang dicekok TKI-RL dengan dosis IF 4,5 mg/ekor/hari dan $6 \mathrm{mg} /$ ekor/hari. Timbulnya gangguan akibat sifat estrogen agonis yang mampu menstimulasi respons estrogen pada kedua dosis isoflavon tersebut menyebabkan penurunan aktivitas aromatase testis tikus, sebagaimana laporan Fritz et al., (2003). Pada tikus, penghambatan aktivitas aromatase dilaporkan menyebabkan penurunan pematangan spermatid (Nitta et al., 1993), sedangkan pada mencit, defisiensi aromatase menyebabkan tertahannya proses awal spermiogenesis (Robertson et al., 1999 diacu dalam Adeoya-Osiguwa et al., 2003). Adanya gangguan spermatogenesis, yaitu penurunan jumlah sel spermatid awal pada mencit yang kondisinya dibuat kekurangan enzim aromatase. Hasil penelitian tersebut menunjukkan bahwa produksi estrogen pada jantan dibutuhkan untuk perkembangan sel benih dan mengontrol spermatogenesis (Robertson et al., 2002).

Terhambatnya atau terganggunya proses spermatogenesis pada kelompok yang dicekok TKI-RL pada dosis IF 4,5 mg/ekor/hari dan 6 $\mathrm{mg} / \mathrm{ekor} /$ hari diduga akibat peningkatan pembentukan radikal bebas karena rusaknya struktur membran plasma mitokondria spermatozoa, sehingga proses oksidasi pada sel testis meningkat. Terjadinya peroksidasi lipid yang terbentuk setelah aksi senyawa radikal dapat diukur melalui pengamatan terhadap kadar MDA. Kelompok yang dicekok TKI-RL dengan dosis IF 4,5 mg/ekor/hari dan 6 $\mathrm{mg}$ /ekor/hari menunjukkan kadar MDA testis tertinggi dan aktivitas enzim superoksida dismutase (SOD) testis sebagai salah satu sistem pertahanan enzim endogen dalam tubuh yang paling rendah. Peningkatan peroksidasi lipid pada kelompok tikus yang dicekok TKIRL dengan dosis IF 4,5 mg/ekor/hari dan 6 $\mathrm{mg}$ /ekor/hari menunjukkan bahwa komponen membran sel testis kedua kelompok tersebut bersifat lebih rentan terhadap reaksi oksidasi sehingga tidak mampu mencegah dan menghambat reaktivitas senyawa radikal bebas dalam tubuh, dan berakibat terhadap peningkatan kerusakan membran sel testis, atau kerusakan membran plasma spermatozoa (Astuti et al., 2008). 
Pengaruh Tepung Kedelai terhadap Testosteron Serum, Jumlah Sel Leydig dan Jumlah Sel Spermatogenik

Tabel 2. Rataan jumlah sel-sel spermatogenik tubuli seminiferi pada tiap tahapan spermatogenesis testis tikus perlakuan dengan berbagai variasi dosis isoflavon.

\begin{tabular}{lcccc}
\hline \hline \multirow{2}{*}{ Perlakuan } & \multicolumn{4}{c}{ Jumlah Sel Kelamin Jantan } \\
\cline { 2 - 5 } & Spermatogonia & Spermatosit & Spermatid Awal & Spermatid Akhir \\
\hline \hline Kontrol, cekok aquades & $40,33 \pm 4,82^{\mathrm{b}}$ & $49,67 \pm 3,81^{\mathrm{b}}$ & $211,22 \pm 16,02^{\mathrm{c}}$ & $130,22 \pm 18,17^{\mathrm{b}}$ \\
Isoflavon 1,5 mg/ekor/hari & $48,44 \pm 4,82^{\mathrm{c}}$ & $60,00 \pm 3,43^{\mathrm{c}}$ & $221,56 \pm 16,12^{\mathrm{c}}$ & $164,33 \pm 17,94^{\mathrm{c}}$ \\
Isoflavon 3 mg/ekor/hari $^{\mathrm{b}}$ & $38,78 \pm 2,77^{\mathrm{b}}$ & $49,33 \pm 5,27^{\mathrm{b}}$ & $192,44 \pm 11,79^{\mathrm{b}}$ & $148,67 \pm 16,11^{\mathrm{c}}$ \\
Isoflavon 4,5 mg/ekor/hari $^{\mathrm{a}}$ & $32,00 \pm 2,45^{\mathrm{a}}$ & $44,67 \pm 4,47^{\mathrm{a}}$ & $170,00 \pm 21,04^{\mathrm{a}}$ & $109,67 \pm 19,91^{\mathrm{a}}$ \\
Isoflavon 6 mg/ekor/hari $^{\mathrm{a}}$ & $29,56 \pm 2,55^{\mathrm{a}}$ & $44,33 \pm 4,72^{\mathrm{a}}$ & $158,78 \pm 10,26^{\mathrm{a}}$ & $106,44 \pm 16,49^{\mathrm{a}}$ \\
\hline \hline
\end{tabular}

Angka yang diikuti oleh huruf yang berbeda pada kolom yang sama menunjukkan adanya perbedaan nyata $(\mathrm{p}<0,05)$.

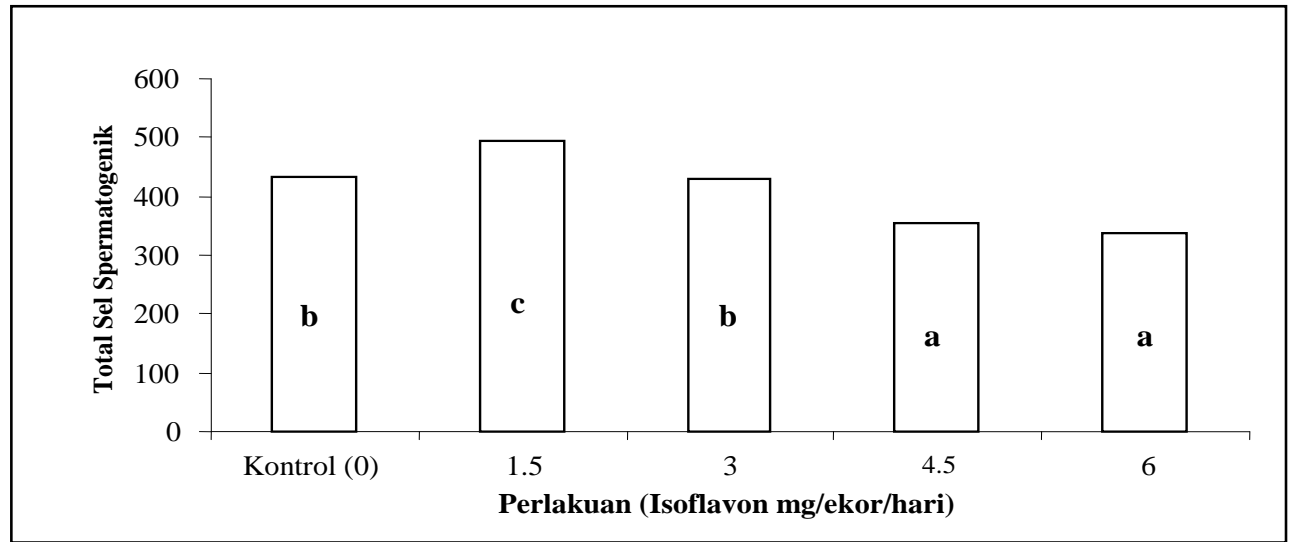

Gambar 4. Rataan total sel spermatogenik tubuli seminiferi pada jaringan testis tikus perlakuan dengan berbagai variasi dosis isoflavon.

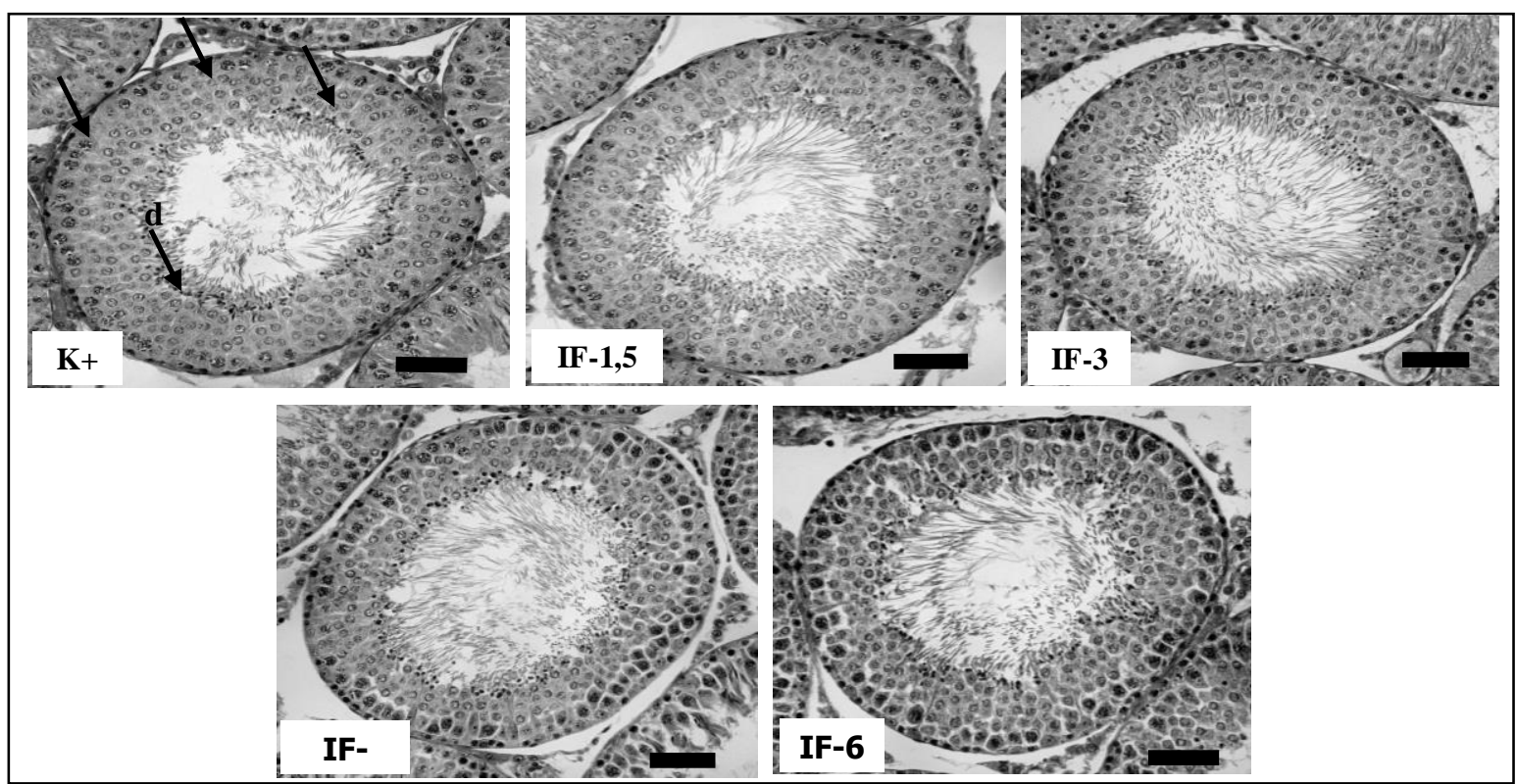

Gambar 5. Fotomikrograf tubuli seminiferi pada testis tikus perlakuan. Kelompok yang mendapat isoflavon pada dosis 4,5 dan $6 \mathrm{mg} / \mathrm{ekor} /$ hari menghasilkan jumlah sel-sel spermatogenik paling rendah secara nyata dibandingkan dengan kelompok lainnya. Pemberian isoflavon pada dosis $1,5 \mathrm{mg} / \mathrm{ekor} / \mathrm{hari}$ menghasilkan jumlah sel spermatogenik paling tinggi secara nyata dibandingkan kelompok yang mendapat isoflavon pada dosis 3; 4,5 dan $6 \mathrm{mg} / \mathrm{ekor} / \mathrm{hari}$. (Pewarnaan HE, skala $=50 \mu \mathrm{m}$ ).

Keterangan $: a=$ Spermatogonia $; b=$ Spermatosit; $c=$ Spermatid Awal; $d=$ Spermatid Akhir.
$\mathrm{K}=$ Kontrol, cekok aquades
I-1,5 = Isoflavon $1,5 \mathrm{mg} / \mathrm{ekor} / \mathrm{hari}$
$\mathrm{I}-3$ = Isoflavon $3 \mathrm{mg} / \mathrm{ekor} / \mathrm{hari}$
$\mathrm{I}-4,5=$ Isoflavon $4,5 \mathrm{mg} / \mathrm{ekor} / \mathrm{hari}$
$\mathrm{I}-6$ = Isoflavon $6 \mathrm{mg} / \mathrm{ekor} / \mathrm{hari}$ 
Menurut O'Connell et al., (2002) selama spermatogenesis, mitokondria dari sel benih jantan mengalami perubahan dan morfologi yang dramatik, yang dapat memulai mutasi mtDNA. Mutasi mtDNA dilaporkan dapat terjadi dan terakumulasi pada spermatid atau selama spermatogenesis, sehingga hal ini akan mengganggu fungsi respirasi mitokondria sebagai organel sel spermatozoa yang memproduksi energi dalam bentuk ATP. Pendapat tersebut didukung oleh pernyataan Kao et al., (1998), bahwa mutasi mtDNA dan kerusakan oksidatif yang disebabkan radikal bebas menyebabkan disfungsi mitokondria. Lebih lanjut dilaporkan bahwa kegagalan proses spermatogenesis disebabkan hilangnya mtDNA, berkaitan dengan berkurangnya jumlah spermatozoa dan dapat menyebabkan kegagalan fungsi reproduksi. Peningkatan radikal bebas pada kelompok yang dicekok TKI-RL dengan dosis IF 4,5 mg/ekor/hari dan 6 $\mathrm{mg} / \mathrm{ekor} / \mathrm{hari}$ yang diperlihatkan dengan tingginya kadar MDA testis dan rendahnya aktivitas enzim SOD testis (Astuti et al., 2008) diduga menyebabkan lebih banyak terjadi kerusakan oksidatif akibat tidak sempurnanya respirasi mitokondria spermatozoa pada kedua kelompok tersebut, sehingga diduga juga mengakibatkan terjadinya mutasi mtDNA.

Dugaan tersebut juga didukung pendapat Atanasssova et al., (2000), bahwa pengaruh senyawa estrogen pada jantan akan menyebabkan perubahan terhadap morfologi testis dan proses spermatogenesis; mengganggu perkembangan testis dan saluran reproduksi, serta menyebabkan perubahan proses spermatogenesis dan gangguan fertilitas (Safe, 2000).

\section{Simpulan dan Saran}

\section{Simpulan}

Pemberian tepung kedelai kaya isoflavon dengan dosis isoflavon yang semakin tinggi menyebabkan peningkatan kadar hormon testosteron serum dan jumlah sel Leydig pada tikus jantan. Dosis isoflavon $1.5 \mathrm{mg} / \mathrm{ekor} / \mathrm{hari}$ merupakan dosis optimum yang menghasilkan total sel spermatogenik tertinggi pada tikus jantan.

\section{Saran}

Masih perlu dilakukan uji klinis untuk mengetahui efektivitas isoflavon yang terkandung dalam tepung kedelai kaya isoflavon.

\section{Ucapan Terima Kasih}

Terima kasih kepada Direktorat Pembinaan Penelitian dan Pengabdian kepada Masyarakat, Ditjen Pendidikan Tinggi Departemen Pendidikan Nasional RI atas dana penelitian yang diberikan melalui Program Hibah Bersaing XIV.

\section{Daftar Pustaka}

Adeoya-Osiguwa, S.S., Markoulaki, S., Pocock, V., Milligan, S.R. dan Fraser, L.R. 2003. 17ßEstradiol and Environmental Estrogens Significantly Affect Mammalian Sperm Function. Human Reproduction, 18 (1): 100-107.

Anonim. 1990. Official Methods of Analysis of the AOAC. AOAC, Inc. Arlington, Virginia.

Anonim. 1998. Indiana Soybean Board: Isoflavone Concentration in Soy Foods. http://www. soyfood.com/nutrition/isoflavoneconcentratio n.html.

Anonim. 2003. Coat-A-Count ${ }^{\circledR}$ Total Testosterone. Corporate Offices, Diagnostic Products Corporation, USA.

Anderson, J.J.B. dan Garner, S.C. 2000. The Soybean as a Source of Bioactive Molecules. In: Schmidl, M.K. and Labuza, T.P. (Eds.). Essentials of Functional Foods. Pp. 239-266. Aspen Publishers, Inc. Gaithersburg, Maryland.

Astuti, S., Muchtadi, D., Astawan, M., Purwantara, B. dan Wresdiyati, T. 2008. Kadar Peroksida Lipid dan Aktivitas Superoksida Dismutase (SOD) Testis Tikus yang Diberi Tepung Kedelai Kaya Isoflavon, Seng ( $\mathrm{Zn})$, dan Vitamin E. Majalah Kedokteran Bandung, 40 (2): 59-66.

Atanassova, N., McKinnell, C., Turner, K.J., Walker, M., Fisher, J.S., Morley, M., Millar, M.R., Groome, N.P. dan Sharpe, R.M. 2000. Comparative Effects of Neonatal Exposure of Male Rats to Potent and Weak (Environmental) Estrogens on Spermatogenesis at Puberty and the Relationship of Adult Testis Size and Fertility: Evidence for Stimulatory Effect of Low Estrogen Levels. Endocrinology 141: 3898-3907. 
Brzozowski, A.M., Pike, A.C.W., Dauter, Z., Hubbard, R.E., Bonn, T., Engstrom, O., Ohman, L., Greene, G.L., Gustafsson, J.A. dan Carlquist, M. 1997. Molecular Basic of Agonism and Antagonism in the Oestrogen Receptor. Nature, 389: 753-758.

Carreau, S., Genissel, C., Bilinska, B. dan Levallet, J. 1999. Sources of Oestrogen in the Testis and Reproductive Tract of the Male. International J. of Andrology, 22: 211-223.

Carreau, S., Lambard, S., Delalande, C., Denis-Galeraud, I., Bilinska, B. dan Bourguiba, S. 2003. Aromatase Expression and Role of Estrogen in Male Gonad: a Review. Reproductive Biology and Endocrinology, 1: 35.

Fritz, W.A., Cotroneo, M.S., Wang, J., Eltoum, I.E. dan Lamartiniere, C.A. 2003. Dietary Diethylstilbestrol But Not Genistein Adversely Affects Rat Testicular Development. J. of Nutrition, 133: 2287-2293.

Hafez, B. dan Hafez, E.S.E. 2000. Reproduction in Farm Animals. Lea and Febiger, Philadephia.

Helferich, G., Allred, C.D. dan Young-Hwa, Ju. 2001. Dietary Estrogens and Antiestrogens. In: Helferich, W. and Winter, C.K. (Eds.). Food Toxicology. Pp. 37-55. CRC Press, Boca Raton.

Hess, R.A. 2003. Estrogen in the Adult Male Reproductive Tract: a Review. Reproductive Biology and Endocrinology, 1: 52.

Janulis, L., Bahr, J.M., Hess, R.A., Janssen, S., Osawa, Y. dan Bunick, D. 1998. Rat Testicular Germ Cells and Epididymal Sperm Contain Active P450 Aromatase. J. of Andrology, 19 (1): 65-71.

Kao, Shu-Huei, Chao, Hsiang-Tai, dan Wei, Yau-Huei. 1998. Multiple Deletions of Mitochondrial DNA are Associated with the Decline of Motility and Fertility of Human Spermatozoa. Molecular Human Reproduction, 4 (7): 657-666.

Kiernan, J.A. 1990. Histological and Histochemical Methods: Theory and Practice. Pergamon Press. Oxford-England.

Luconi, M., Forti, G. dan Baldi, E. 2002. Genomic and Nongenomic Effect of Oestrogens: Molecular Mechanisms of Action and Clinical Implications for Male Reproduction. $J$. Steroid Biochemistry \& Molecular Biology, 80: 369-381.
Miksicek, R.J. 1994. Interaction of Naturally Occuring Nonsteroidal Estrogens with Expressed Recombinant Human Estrogen Receptor. J. Steroid Biochemistry \& Molecular Biology, 49: $153-160$.

Mitchell, J.H., Elizabeth, C., Kinnibeurgh, D., Provan, A., Collins, A.R. dan Irvine, D.S. 2001. Effect of a Phytoestrogen Food Supplement on Reproductive Health in Normal Males. Clinical Science, 100: 613-618.

Nijveldt, R.J., van Nood, E., van Hoorn, D.E.C., Boelens, P.G., van Norren, K. dan van Leeuwen, P.A.M. 2001. Flavonoids: a Review of Probable Mechanism of Action and Potential Applications. American J. of Clinical Nutrition, 74: 418-425.

Nitta, H., Bunick, D., Hess, R.A., Janulis, L., Newton, S., Millette, C., Osawa, Y., Shizuta Y., Toda, K. dan Bahr, J.M. 1993. Germ Cells of the Mouse Testis Express P450 Aromatase. Endocrinology, 132: 1396-1401.

O'Connell, M., McClure, N. dan Lewis, S.E. 2002. Mitochondrial DNA Deletions and Nuclear DNA Fragmentation in Testicular and Epididymal Human Sperm. Human Reproduction, 17: 1565-1570.

Robertson, K.M., O’Donnell, L., Simpson, E.R. dan Jones, M.E.E. 2002. The Phenotype of the Aromatase Knockout Mouse Reveals Dietary Phytooestrogens Impact Significantly on Testis Function. Endocrinolology, 143 (8): 2913-2921.

Safe, S. 2000. Endocrine Disruptors and Human Health is there a Problem? An Update. Environmental Health Perspectives, 108: 487-493.

Sanocka, D. dan Kurpisz, M. 2004. Reactive Oxygen Species and Sperm Cells. Reprod. Biol. Endocrinol, 2: 12.

Sikka, S.C. 2004. Role of Oxidative Stress and Antioxidants in Andrology and Assisted Reproductive Technology. J. of Andrology, 25 (1): 5-18.

Tendean, O.S. 2005. Terapi Sulih Testosteron pada Gangguan Spermatogenesis. Di dalam Buku Kumpulan Makalah/Abstrak. Andrologi: Sesuatu yang Hilang dalam Kesehatan Reproduksi untuk Meningkatkan Kualitas Hidup Manusia. Kongres Pandi IX dan Kongres Persandi I. 19-23 April. Jakarta. 